\title{
NEW K-Ar COOLING AGES OF GRANITOIDS FROM THE STRZEGOM- SOBÓTKA MASSIF, SW POLAND
}

\author{
KRZYSZTOF TURNIAK ${ }^{1}$, STANISLAW HALAS ${ }^{2}$ and ARTUR WÓJTOWICZ ${ }^{2}$ \\ ${ }^{I}$ Institute of Geological Sciences, Wroctaw University, \\ M. Borna 9, 50-205 Wrocław \\ ${ }^{2}$ Institute of Physics, Maria Curie-Sklodowska University, \\ Plac Marii Curie-Skłodowskiej 1, 20-031 Lublin, Poland
}

\begin{abstract}
The Strzegom-Sobótka Variscan Massif (Fore-Sudetic Block, NE Bohemian Massif) consists of various post-kinematic Variscan granitoids emplaced into Palaeozoic low grade metamorphic rocks. Biotite from five samples representing the hornblende-biotite monzogranite, biotite monzogranite and biotite granodiorite has been dated using the K-Ar method for two size-fractions (0.250.35 and $0.35-0.5 \mathrm{~mm}$ ). Finer fractions show more intense chloritization and therefore the results for them were rejected in further discussion. Coarser fractions with higher potassium content were accepted as yielding a maximum estimate approaching the true $\mathrm{K}-\mathrm{Ar}$ biotite cooling ages. The results are clustered in two groups. The older age group (308.8 $\pm 4.6 \mathrm{Ma}$ and $305.5 \pm 4.3 \mathrm{Ma}$ ) comprises results obtained from the biotite granodiorites. They are generally consistent with the zircon crystallization age of 308.4 \pm 1.7 Ma reported by Turniak et al. (2005) and imply rapid cooling of the biotite granodiorite from magmatic temperatures down to the closure temperature of K-Ar isotopic system in biotite. The younger group is defined by $291.0 \pm 4.4 \mathrm{Ma}$ and $298.7 \pm 5.2 \mathrm{Ma}$ ages for the hornblende-biotite monzogranite and 294.2 $\pm 4.3 \mathrm{Ma}$ age for the biotite monzogranite. In the absence of precise $\mathrm{U}-\mathrm{Pb}$ or $\mathrm{Pb}-\mathrm{Pb}$ zircon data further geochronological studies are needed to decipher precisely the cooling history of the monzogranites.
\end{abstract}

Keywords: Variscan granitoids, biotite, cooling age, K-Ar dating, Strzegom-Sobótka Massif

\section{INTRODUCTION}

The Strzegom-Sobótka Massif (SSM), composed of various Variscan post-kinematic granitoids, is situated in the central part of the Fore-Sudetic block (NE Bohemian Massif; Fig. 1). Four main rock varieties exposed in SSM - hornblende-biotite monzogranite and biotite monzogranite (in the west of SSM), two-mica monzogranite (in the centre) and biotite granodiorite (in the east) are interpreted by Puziewicz (1985) as separate intrusions. Details on their petrography and geochemistry are given by Kural and Morawski (1968), Majerowicz (1972) and Puziewicz (1990).

Based on $\mathrm{Rb}$-Sr investigations, the massif was shown to be a complex body with at least two stages of development: intrusion of the two-mica granite $(324 \pm 7 \mathrm{Ma})$

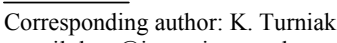

e-mail: ktur@ing.uni.wroc.pl

ISSN 1897-1695 (online) (C) 2007 GADAM Centre,

Institute of Physics, Silesian University of Technology.

All rights reserved. followed by emplacement of the biotite granodiorite and monzogranites dated at about $280 \mathrm{Ma}$ (Pin et al., 1989). The latter age was also confirmed by Domańska-Siuda et al. (2004) for the hornblende-biotite monzogranite. Ages of $309.1 \pm 0.8 \mathrm{Ma}$ and $306.4 \pm 0.8 \mathrm{Ma}$ were obtained from two-mica granite using ID-TIMS method on monazite and xenotime, respectively (Turniak and Bröcker, 2002). The emplacement age of the biotite granodiorite was established at $308.4 \pm 1.7$ Ma by Turniak et al. (2005) on the basis of $\mathrm{Pb}$-evaporation zircon datings. The hornblende-biotite and biotite monzogranites yielded a spectrum of zircon ${ }^{207} \mathrm{~Pb} /{ }^{206} \mathrm{~Pb}$ ages: $299 \pm 8 \mathrm{Ma}$ (Paszowice),

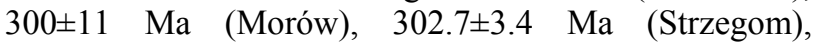
306.6 $\pm 4.2 \mathrm{Ma}$ (Kostrza) and 307.2 $\pm 4.4 \mathrm{Ma}$ (Graniczna). Comparable results of 304-309 Ma are reported from ReOs studies on molybdenite from quartz veins crosscutting the hornblende-biotite granite exposed in the Paszowice quarry (Mikulski and Stein, 2005). 


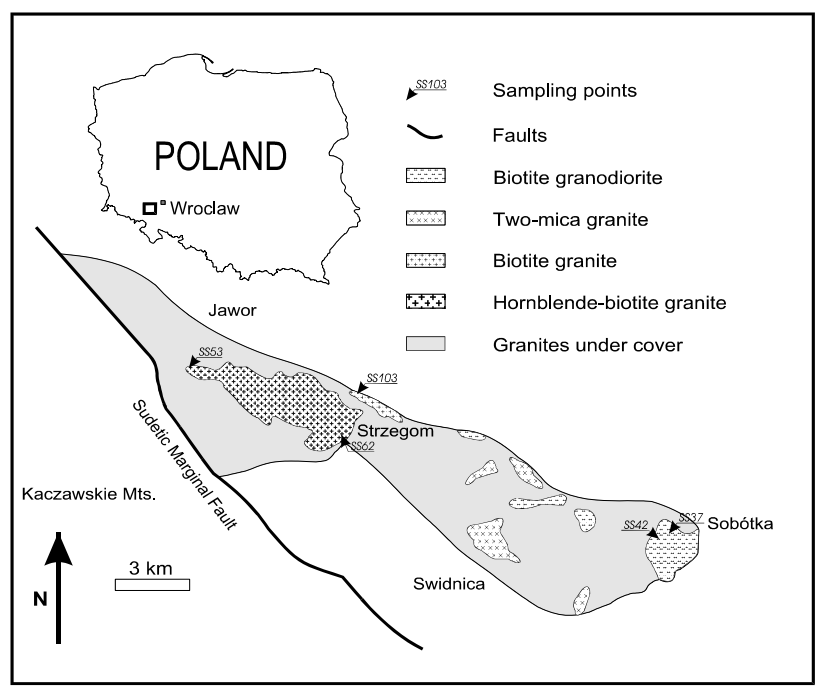

Fig. 1. Geological sketch map of the Strzegom-Sobótka Massif with sampling points (based on Majerowicz, 1972).

Although the ages of individual intrusions comprised in SSM seem to be well estimated, the cooling history of the massif remains poorly constrained. Early K-Ar investigations on biotites extracted from the granitoids revealed a wide age range from 224 to 318 Ma (Borucki, 1966). Depciuch (1971), using the same isotopic system and mineral, obtained about $266 \mathrm{Ma}$.

In this study, we report new results of biotite $\mathrm{K}-\mathrm{Ar}$ dating for 5 samples representing the hornblende-biotite monzogranite, biotite monzogranite and biotite granodiorite of SSM. Our study provides first isotopic evidence for different cooling histories of the granitoids exposed in the western and eastern parts of the Strzegom-Sobótka Massif.

\section{ANALYTICAL PROCEDURES}

The rock samples were crushed using a jaw crusher and sieved into $0.25-0.35$ and $0.35-0.5 \mathrm{~mm}$ size-fractions. The material was then washed in water and dried in an oven in temperature at about $50^{\circ} \mathrm{C}$. Magnetic separation, paper-shaking and handpicking under a binocular microscope produced about $300 \mathrm{mg}$ biotite separates which were subsequently cleaned in distilled water in an ultrasonic bath.

The potassium concentrations in the biotite samples were determined by AAS using a Pye Unicam SP9 spectrophotometer at the Institute of Geological Sciences, University of Wrocław. Argon was analysed using a modified mass spectrometer MS-10 at the Institute of Physics of the Maria Curie-Skłodowska University in Lublin. A low blank ultra-high-vacuum line described by S. Halas (2007) was used for argon extraction and purification. For $\mathrm{K}-\mathrm{Ar}$ age calculation the constants $\lambda_{\mathrm{e}}=0.581 * 10^{-10} 1 / \mathrm{a}, \lambda_{\beta}=4.962 * 10^{-10} 1 / \mathrm{a},{ }^{40} \mathrm{~K} / \mathrm{K}=0.01167 \%$ (Steiger and Jaeger, 1977) were adopted. Uncertainty in the $\mathrm{K}-\mathrm{Ar}$ age was calculated from the error propagation formula.

Chemical composition of the biotite was investigated by a CAMECA SX-100 electron-microprobe (WDS mode) in the Electron Microprobe Laboratory at the In-
ter-Institute Microanalytical Complex for Minerals and Synthetic Substances, Warsaw University. Measurement conditions were as follows: $10 \mathrm{nA}$ beam current, accelerating voltage $15 \mathrm{kV}$ and counting time $20 \mathrm{~s}$. The PAP procedure was employed for matrix correction.

XRD analyses were carried out for SS62 sample to compare semi-quantitively chlorite admixtures in the biotite fractions analysed. For each fraction an oriented mount with uniform thickness was prepared. X-ray diffraction patterns were obtained at the Institute of Geological Sciences, University of Wrocław, using a Siemens 5005 instrument operating at $30 \mathrm{kV}, 25 \mathrm{~mA}$ and $\mathrm{CoK}_{\alpha 1}$ Fe-filtered radiation. Scans were made from $4^{\circ}$ to $75^{\circ} 2 \Theta$ with a step of $0,02^{\circ} 2 \Theta$ and a step-time of $1 \mathrm{~s}$.

\section{BIOTITE DESCRIPTION}

Ten biotite concentrates extracted from 5 granitoid samples were analysed using the K-Ar isotope method. They represent three of four main lithological varieties of the Strzegom-Sobótka Massif: biotite granodiorite (SS37 - Strzeblów, SS42 - Chwałków), hornblende-biotite monzogranite (SS53 - Paszowice, SS62 - Strzegom, "Żbik" quarry) and biotite monzogranite (SS103 "Graniczna I" quarry). The sampling sites are indicated in Fig. 1.

The biotite forms mostly subhedral to anhedral plates up to $2 \mathrm{~mm}$ long, sometimes grouped into aggregates. Grain boundaries are often ragged or lobate (Fig. 2). Pleochroic colour for $\gamma$ direction change gradually from cinnamon-brown (the biotite granodiorite) through redbrown (the biotite monzogranite) to dark-brown, almost black (the hornblende-biotite monzogranite). Heavy minerals - apatite, ilmenite, zircon and allanite are common inclusions in the mica from hornblende-biotite monzogranite. Additionally monazite an xenotime are found in the biotite from the granodiorite and biotite monzogranite. The biotite is partly replaced by chlorite mainly along cleavage planes, fractures and marginal parts of grains (Fig. 2).

The biotite composition changes from biotite granodiorite through biotite monzogranite to hornblende-biotite monzogranite manifested mainly by the decrease of $\mathrm{Al}$ and $\mathrm{Si}$ contents coupled with the increase of $\mathrm{Fe}^{2+} /\left(\mathrm{Fe}^{2+}+\mathrm{Mg}\right)$ ratio (Table 1). It corroborates findings reported previously by Wichrowska (1974 and 1977) and Puziewicz (1994). Biotite from the biotite granodiorite shows the highest concentrations of $\mathrm{Al}$, occupying both tetrahedral and octahedral sites, whereas the mica from the hornblende-biotite monzogranite contains less Al than necessary to substitute for $\mathrm{Si}^{4+}$ implying that possibly also $\mathrm{Fe}^{3+}$ is confined in the tetrahedral sites. The $\mathrm{Fe}^{2+} /\left(\mathrm{Fe}^{2+}+\mathrm{Mg}\right)$ ratio is $0.59-0.63$ for the biotite granodiorite, $0.68-0.71$ for the biotite monzogranite and $0.78-0.83$ for the hornblende-biotite monzogranite. Potassium content in the pristine biotite is highest in the biotite granodiorite (SS37: 7.92(12)wt.\%, SS42: 7.90(15)wt.\%). Smaller concentrations were shown by samples representing the hornblende-biotite monzogranite (SS62: 7.65(14)wt. \%, SS53: 7.73(8)wt.\%) and biotite monzogranite (SS103: 7.60(15)wt.\%). It is worth to note that 


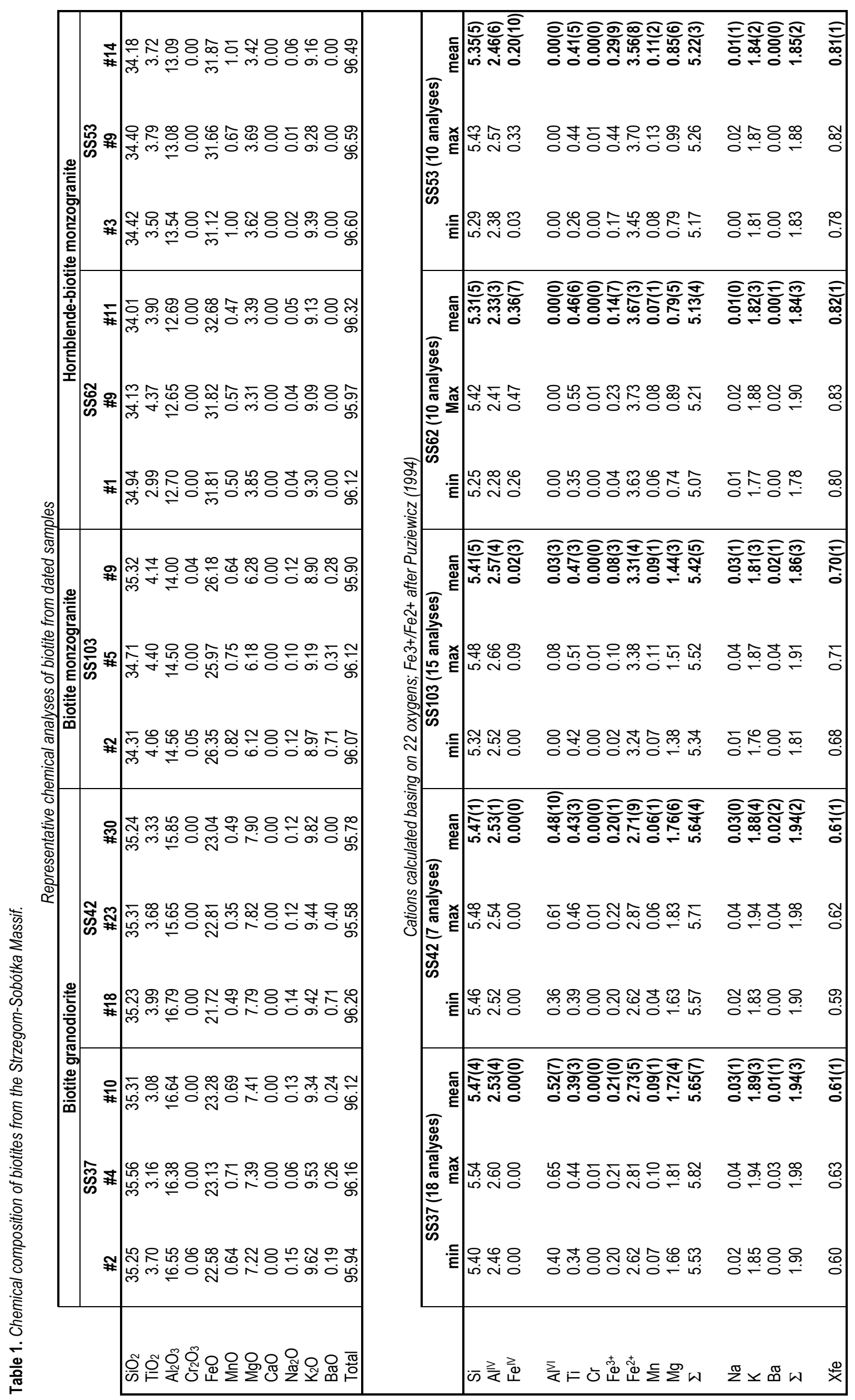




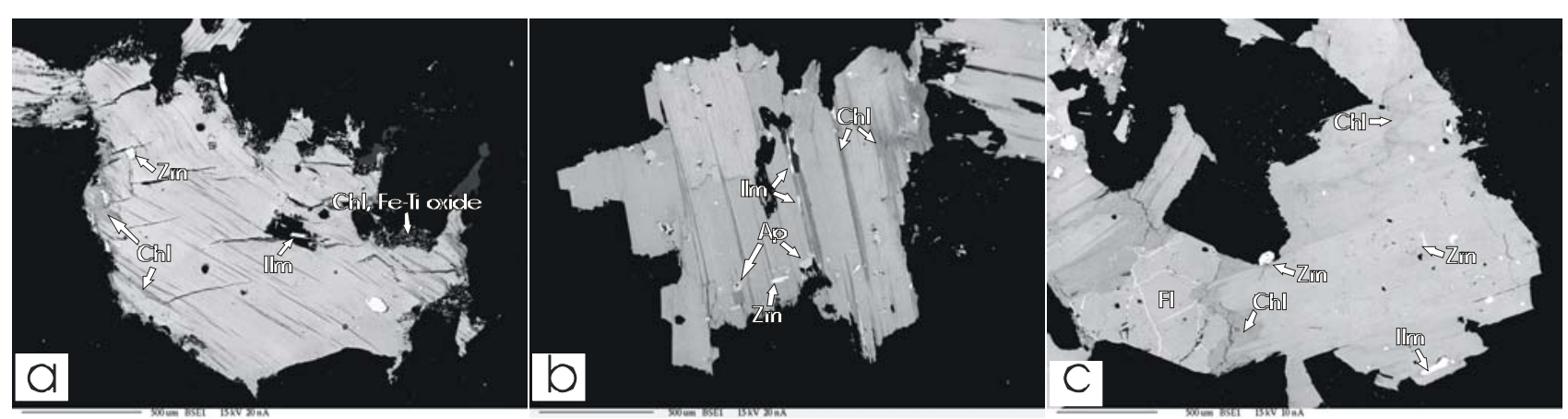

Fig. 2. Back-scattered electron images of biotites from the Strzegom-Sobótka Massif. a) Deformed biotite crystal from the biotite granodiorite (SS42) partly replaced by chlorite. b) Biotite plate from the biotite monzogranite with chlorite interlayers developed along biotite cleavage. c) Aggregate of biotite individuals from the hornblende-biotite granite (SS62). Chlorite distributed along fractures, cleavage and in the vicinity of fluorite grain. Mineral abbreviations after Kretz (1983).

chemical analyses of the biotite from the granodiorite show slightly elevated $\mathrm{Ba}$ concentrations suggesting that $\mathrm{Ba}^{2+}$ partly replaces $\mathrm{K}^{+}$in the interlayer site.

\section{RESULTS AND DISCUSSION}

The results of $\mathrm{K}-\mathrm{Ar}$ isotopic analyses are summarized in Table 2. The K-Ar ages decrease while $\mathrm{K}$ contents increase consequently with a particle size of the analysed material. On the other hand, ${ }^{40} \mathrm{Ar}^{*}$ concentrations are similar for different fractions of the same sample. The exception is SS42 where the coarser fraction yielded ${ }^{40} \mathrm{Ar}^{*}$ of $4087 \mathrm{pmol} / \mathrm{g}$ and the age of $305.5 \pm 4.3 \mathrm{Ma}$, whereas the finer one $-4428 \mathrm{pmol} / \mathrm{g}$ and $334.5 \pm 5.8 \mathrm{Ma}$. The latter result is significantly higher than the zircon $\mathrm{Pb}-\mathrm{Pb}$ age obtained for the biotite granodiorite (308.4 $\pm 1.7 \mathrm{Ma}$; Turniak et al., 2005) and therefore probably meaningless geologically. Abundances of potassium measured by AAS for the biotite separates are below EPMA values recorded for pristine biotite. It can be explained assuming that chlorite and/or inclusions of heavy minerals were present in the AAS samples analysed. To verify this, XRD study was carried out for the biotite separates from sample SS62. Both XRD patterns are characterised by intense reflections corresponding to biotite (001) spacings with weak peaks of chlorite. No other mineral was detected in the sample. The intensity ratios $(003)_{\text {biotite }} /(004)_{\text {chlorite }}$ of 100/4 and 100/8 obtained for fractions $0.35-0.5$ and $0.25-0.35 \mathrm{~mm}$ respectively testify that the latter fraction is more contaminated by

Table 2. K-Ar ages for the granitoids of the Strzegom-Sobótka Massif.

\begin{tabular}{|c|c|c|c|c|c|c|c|}
\hline Sample & $\begin{array}{l}\text { Fraction } \\
(\mathrm{mm})\end{array}$ & $\begin{array}{c}K \\
(\%)\end{array}$ & $\begin{array}{c}\text { Error } \\
(\%)\end{array}$ & $\begin{array}{l}{ }^{40} \mathrm{Ar}^{*} \\
(\mathrm{pmol} / \mathrm{g})\end{array}$ & $\begin{array}{l}{ }^{40} \mathrm{Ar}^{*} \\
(\%)\end{array}$ & $\begin{array}{l}\text { Age } \\
\text { (Ma) }\end{array}$ & $\begin{array}{l}\text { Error } \\
(2 \sigma)\end{array}$ \\
\hline SS37 & $0.25-0.35$ & 7.32 & 0.56 & 4337 & 98.3 & 312.9 & 4.7 \\
\hline SS37 & $0.35-0.5$ & 7.42 & 0.56 & 4334 & 98.4 & 308.8 & 4.6 \\
\hline SS42 & $0.25-0.35$ & 6.95 & 0.52 & 4428 & 97.5 & 334.5 & 5.8 \\
\hline SS42 & $0.35-0.5$ & 7.08 & 0.50 & 4087 & 98.4 & 305.5 & 4.3 \\
\hline SS62 & $0.25-0.35$ & 6.97 & 0.59 & 3875 & 93.1 & 295.1 & 5.0 \\
\hline SS62 & $0.35-0.5$ & 7.20 & 0.57 & 3942 & 97.8 & 291.0 & 4.4 \\
\hline SS53 & $0.25-0.35$ & 6.59 & 0.62 & 3800 & 98.1 & 305.2 & 4.9 \\
\hline SS53 & $0.35-0.5$ & 6.82 & 0.52 & 3841 & 98.1 & 298.7 & 5.2 \\
\hline SS103 & $0.25-0.35$ & 7.42 & 0.56 & 4164 & 85.4 & 297.7 & 5.9 \\
\hline SS103 & $0.35-0.5$ & 7.54 & 0.54 & 4178 & 98.4 & 294.2 & 4.3 \\
\hline
\end{tabular}

chlorite. Many studies have shown that chlorite contamination of biotite separates disturbs K-Ar and ${ }^{40} \mathrm{Ar}-{ }^{39} \mathrm{Ar}$ age spectra (e.g. Mitchell and Taka, 1984; Roberts et al., 2001, Di Vincenzo et al. 2003). Consequently, since coarser fractions contain least chlorite and highest potassium content, it is most correct to reject K-Ar results based on $0.25-0.35 \mathrm{~mm}$ fractions and accept remaining values as yielding a maximum estimate that approach the true K-Ar biotite cooling ages.

The K-Ar cooling ages presented in this paper are clustered in two groups. The older age group $(308.8 \pm 4.6 \mathrm{Ma}$ and $305.5 \pm 4.3 \mathrm{Ma})$ comprises results obtained from the biotite granodiorites. They are generally consistent within error limits with the zircon crystallisation age reported by Turniak et al. (2005) that implies a rapid cooling of the biotite granodiorite exposed in the eastern part of SSM from magmatic temperatures down to the closure temperature of $\mathrm{K}-\mathrm{Ar}$ isotopic system in biotite $\left(300 \pm 50^{\circ} \mathrm{C}\right.$; Dodson and McClelland-Brawn, 1985). This is consistent with earlier conclusions based on the outcomes of petrological studies (Kural and Morawski, 1968) according to which the brittle deformed granodiorites from the eastern part of SSM were first to experience consolidation.

The younger group is defined by $291.0 \pm 4.4 \mathrm{Ma}$ and 298.7 $\pm 5.2 \mathrm{Ma}$ ages for the hornblende-biotite monzogranite and 294.2 $\pm 4.3 \mathrm{Ma}$ age for the biotite monzogranite. A similar age of $290.5 \pm 6.6 \mathrm{Ma}(\mathrm{Rb}-\mathrm{Sr}$, wholerock) was obtained by Domańska-Siuda (2006) for hornblende-biotite monzogranite and enclosed mafic enclaves. The biotite monzogranite was probably emplaced $307.2 \pm 4.4 \mathrm{Ma}$ as indicated by $\mathrm{Pb}-\mathrm{Pb}$ zircon evaporation data (Turniak et al., 2005). This age is in agreement within error limits with the results obtained for the granodiorites. Maciejewski and Morawski (1975) reported a several $\mathrm{cm}$ thick vein of the hornblende-biotite granite cutting across the biotite monzogranite suggesting that the first rock was emplaced later. Following their observation, it seems plausible that the late K-Ar cooling age of the biotite monzogranite can be explained by thermal influence of the adjacent hornblende-biotite monzogranite which records similar cooling ages.

In the absence of exact $\mathrm{U}-\mathrm{Pb}$ or $\mathrm{Pb}-\mathrm{Pb}$ zircon data, a minimum emplacement age for the hornblende-biotite monzogranites is probably best constrained by the 
304-309 Ma molybdenite cooling ages (Mikulski and Stein, 2005). Comparing $\mathrm{K}-\mathrm{Ar}$, $\mathrm{Re}-\mathrm{Os}$ and $\mathrm{Pb}-\mathrm{Pb}$ ages for the biotite granodiorite and hornblende-biotite monzogranite it might be suggested that the latter was subjected to slower cooling. Further geochronological studies are needed to precisely decipher the cooling history of the monzogranite.

\section{ACKNOWLEDGEMENTS}

This project was supported by 2022/W/ING/06 research grant.

\section{REFERENCES}

Borucki J, 1966. Wstępne wyniki datowań bezwzględnych (K-Ar) granitoidów dolnośląskich (Preliminary results of K-Ar dating of the Lower Silesia granitoids). Kwartalnik Geologiczny 10: 1-18 (in Polish).

Depciuch T, 1971. Wiek bezwzględny granitoidów strzegomskich określony metodą K-Ar (Absolute age of Strzegom granitoids determined by K-Ar method). Kwartalnik Geologiczny 15: 862-869 (in Polish).

Di Vincenzo G, Viti C and Rocchi S, 2003. The effect of chlorite interlayering on ${ }^{40} \mathrm{Ar}-{ }^{39} \mathrm{Ar}$ biotite dating: an ${ }^{40} \mathrm{Ar}-{ }^{39} \mathrm{Ar}$ laser-probe and TEM investigations of variably chloritised biotites. Contribiutions to Mineralogy and Petrology 145: 643-658.

Domańska-Siuda J, 2006. Origin and evolution of mother melt ofthe hornblende-biotite granite of western part of the Strzegom massif (in Polish). PhD Thesis, Archiwum Uniwersytetu Warszawskiego: 176 pp.

Domańska-Siuda J, Bachliński R and Słaby E, 2004. Rb-Sr and Sm-Nd isotopic study of hornblende-biotite granite from the StrzegomSobótka massif and its enclaves. VIII Ogólnopolska Sesja Naukowa: Datowanie Mineratów i Skat: 11-14.

Dodson MH and McClelland-Brawn E, 1985. Isotopic and paleomagnetic evidence for rates of cooling, uplift and erosion. Geological Society of America Memoirs 10: 315-325.

Halas S, 2007. Low-blank crucible for Ar extraction from minerals at temperatures up to $1550^{\circ}$ C. Geochronometria 27: 1-3, DOI 10.2478/v10003-007-0014-1.

Kretz R, 1983. Symbols for rock-forming minerals. American Mineralogist 68: 277-279.

Kural S and Morawski T, 1968. Strzegom-Sobótka granitic massif. Biuletyn Instytutu Geologicznego 227: 33-74.

Maciejewski S and Morawski T, 1975. Zmienność petrograficzna granitów masywu strzegomskiego (Petrographic variability of granites from Strzegom Massif). Kwartalnik Geologiczny 19(1): 4765 (in Polish).
Majerowicz A, 1972. Masyw granitowy Strzegom-Sobótka. Studium petrologiczne (Strzegom-Sobótka granitic massif. Petrological study). Geologia Sudetica 6: 7-88 (in Polish).

Mikulski SZ and Stein HJ, 2005. The Re-Os age for molybdenite from the Variscan Strzegom-Sobótka massif, SW Poland. In: Jingwen Mao and Frank P. Bierlein, eds, Mineral Deposit Research: Meeting the Global Challenge: 789-792. Springer.

Mitchell JG and Taka AS, 1984. Potassium and argon loss patterns in weathered micas: implications for detrital mineral studies, with particular reference to the Triassic palaeogeography of the British Isles. Sedimentary Geology 39: 27-52.

Pin C, Puziewicz J and Duthou JL, 1989. Ages and origins of a composite granitic massif in the Variscan belt: a Rb-Sr study of the Strzegom-Sobótka Massif, W Sudetes (Poland). Neues Jahrbuch für Mineralogie - Abhandlungen 160: 71-82.

Puziewicz J, 1985. Petrologia skał masywu granitowego StrzegomSobótka (Petrology of rocks from Strzegom-Sobótka granitic massif. Conference Proceedings „Petrologia skat masywu granitowego Strzegom-Sobótka i jego ostony”: 19-27 (in Polish).

Puziewicz J, 1990. Masyw granitowy Strzegom-Sobótka. Aktualny stan badań (Strzegom-Sobótka granitic massif. Recent state of studies). Archiwum Mineralogiczne 45: 135-152 (in Polish).

Puziewicz J, 1994. Zawartość tytanu w biotycie $\mathrm{z}$ granitoidów jako wskaźnik warunków krystalizacji magmy. Studium biotytu z metaaluminowych granitoidów masywu Strzegom-Sobótka (Titanium content in biotite from granitoids as indicator of magma crystalization conditions. Study of biotite in metaaluminic granitoids of Strzegom-Sobótka Massif). Archiwum Mineralogiczne 50(1): 89-134 (in Polish).

Roberts HJ, Kelley SP and Dahl PS, 2001. Obtaining geologically meaningful ${ }^{40} \mathrm{Ar}-{ }^{39} \mathrm{Ar}$ ages from altered biotite. Chemical Geology 172: $277-290$.

Steiger RH and Jaeger E, 1977. Subcommision on geochronology: convention on the use of decay constants in geo- and cosmochronology. Earth and Planetary Science Letters 36: 359-362.

Turniak K and Bröcker M, 2002. Age of the two-mica granite from the Strzegom-Sobótka massif: new data from $\mathrm{U} / \mathrm{Pb}$ monazite and xenotime study. Mineralogical Society of Poland - Special Papers 20: 211-213.

Turniak K, Tichomirowa $\mathrm{M}$ and Bombach K, 2005. Zircon Pbevaporation ages of granitoids from the Strzegom-Sobótka Massif (SW Poland). Mineralogical Society of Poland - Special Papers 25: 241-245.

Wichrowska M, 1974. Biotyty z granitów strzegomskich (Biotites from Strzegom granites). Kwartalnik Geologiczny 18(1): 33-43 (in Polish).

Wichrowska M, 1977. Pierwiastki śladowe w łyszczykach z granitoidów masywu Strzegom-Sobótka i Strzelin-Žulová (Trace elements in micas from granitoids of Strzegom-Sobótka and Strzelin-Žulová Massif). Biuletyn Instytutu Geologicznego 298: 209-261 (in Polish). 